\title{
Methods of Covid-19 Crisis Management in the International Tourism and Civil Aviation Transport
}

\author{
Jindrich Ploch \\ College of International and Public Relations Prague (CIPR), Czech Republic \\ Monika Palatková \\ College of International and Public Relations Prague (CIPR), Czech Republic
}

\section{Abstract}

Tourism and air transport are among the sectors most affected by the Covid-19 crisis. The pandemic lasting more than a year is reflected in short-term effects in both sectors, but there are also severe long-term consequences. National authorities will have to set recovery plans following the relevant policies and encompass international cooperation with public and private entities. The article aims to identify the methods and procedures that can be implemented, which can mitigate the consequences of the crisis and initiate the renewal of international tourism and air transport in particular. The paper's methodology is based on current statistical data and strategic documents at the national and international level represented by the international organizations (esp. UNWTO, WTTC, IATA, ICAO, ECAC). The focus is on the crisis management of the public sector entities in terms of the definition and implementation of reconstruction strategies, on private sector stakeholders, on the interconnection of the tourism and the air transport sectors, and cooperation in the international environment. Methods and tools for the renewal of both sectors are based on a strategic approach of the public sector, support for the introduction of new business models in the private sector, change in the product and marketing mix, digitization, innovation, and education.

Keywords: international tourism, international air transportation, tourism policy, transportation policy, crisis management, strategic management JEL classification: H12, H50, L83, L9, R4

Paper type: Research article

Received: Mar 15, 2021

Accepted: Sep 2, 2021

DOI: 10.54820/PKYG2115 


\section{Introduction}

Tourism and air transport sectors were among the economic sectors most affected by the pandemic of the covid-19. The dramatic drop in the tourism and air transport demand started in spring 2020 and has continued up to these days.

The specific circumstances forced private companies in both of the mentioned sectors to adopt short-term crisis management scenarios and measures to overcome the first month of the pandemic. As a result of a worsened situation in 2020 and the beginning of 2021, many private companies decided to stop their activities, reduce them, or adopt long-term strategic plans based on previously gained experience.

The measures and rules approved and implemented by the public sector focused on the financial and non-financial field, but very often without using relevant data, launching scenarios, and without using principles and methods of strategic planning. The risk of the mentioned procedures consists of spending public money haphazardly without defining the roadmap, clear goals, and how to reach them. The decision-makers experts have not consistently demonstrated the ability to make crisis decisions. A visual deficit in the setting of crisis and strategic recovery measures leads to heavy losses on all levels. All-Dabagh (2020) draws attention to "...the role of decision-makers in times of crisis (COVID-19 pandemic as a model) to illustrate how the decision-makers should make positive decisions in crisis, strategies and skills and roles of them in crisis management".

The article aims to identify the methods and procedures that can be implemented to help solve the consequences of the crisis and start the renewal of international tourism and air transport. The paper's methodology is based on current statistical data and strategic documents at the national and international level represented by the international organizations (UNWTO, WTTC, IATA, ICAO, ECAC).

\section{Methodology}

The methodology is based on the content analysis of selected strategic documents and recommendations published by the leading international organizations in the field of international tourism and air transport: UNWTO (UN World Tourism Organisation), WTTC (World Travel and Tourism Council), IATA (International Air Transport Association), ICAO (International Civil Aviation Organization), ECAC (European Civil Aviation Conference).

The set of the analyzed documents consists of research studies, strategic recommendations, recovery "protocols" for specific subsectors (e.g. tour operators, attractions), research studies based on the expert opinion of influencers and decision-makers in both sectors:

- UNWTO Global guidelines to restart tourism (05/2020) (UNWTO, 2020e),

- UNWTO: Supporting jobs and economies (04/2020) (UNWTO, 2020h),

- UNWTO: Covid-19 tourism recovery technical assistance package (UNWTO, 2020b),

- UNWTO: Measures to Support Travel and Tourism (UNWTO, 2020c),

- WTTC: To recovery \& beyond: The future of travel \& tourism in the wake of Covid-19 (WTTC, 2020b),

- ECAC: Europe's Vision for Aviation Flightpath 2050 (European Commission, 2021),

- IATA: COVID-19 Outlook for air travel in the next five years (Pearce, 2020),

- ICAO: Global Market Forecast (Prevor, 2018),

The research question is what international organizations propose crisis management methods and recommendations for revitalizing both sectors. Selected 
statistical data (UNWTO, WTTC, Czech Statistical Office, ECAC, IATA) for the past period and future development scenarios of tourism and air transport development are used as supportive analytical sources.

\section{Results}

The impact of the pandemic on the tourism and air transportation market

According to the UNWTO, tourism represents a social, cultural, and economic phenomenon covering the movement of people to countries or places outside their usual environment for personal or business/professional purposes. The movement and other activities of visitors/tourists / one-day visitors are connected with consumption and tourism expenditure. International tourism comprises inbound and outbound tourism, which means the activities of resident visitors outside the country of residence, either as part of domestic or outbound tourism trips, and the activities of non-resident visitors within the country of reference on inbound tourism trips (UNWTO, 2008).

The position of tourism in the world economy in 2019 is given by the impact of tourism on world GDP of $10.3 \%$ (total impact) and the impact on employment (330 million jobs). According to the WTTC, every fourth new job in the world economy has been created in tourism in the last five years (WTTC, 2020a).

Whether for economic or non-economic reasons, the path of tourism market recovery and the dynamics associated with it have always been very fast in history. During the post-war period, there were only a few times a decrease in international tourism arrivals $(1982,2001,2003,2009)$ accompanied mostly by a decrease in income from international tourism, but so far it has never meant a decline in the entire industry. The recovery speed after these declines was given not only by the vitality of direct and indirect sectors but also by the coordination of international cooperation. The current crisis in world tourism caused by the pandemic means an unprecedented crisis in the economic and social fields. Possible recovery scenarios are depicted in Figure 1. 
Figure 1

Scenarios for further development of international arrivals

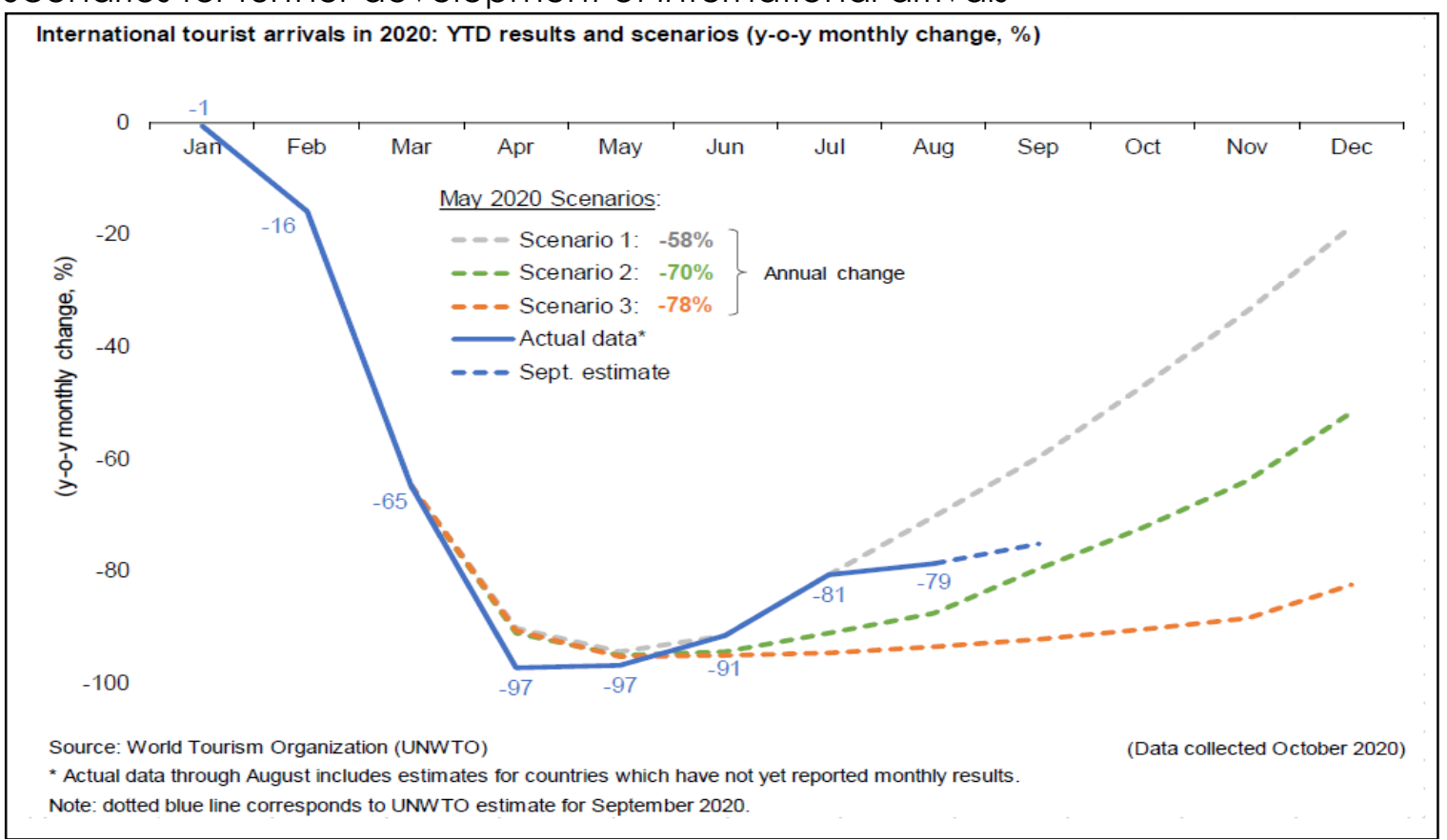

Source: UNWTO, 2020f

An analysis of the UNWTO Tourism Confidence Index (TCl) indicates the following possible trends based on the opinions of the results of an email survey (Panel of Tourism Experts). The UNWTO $\mathrm{TCl}$ aims to collect opinions from tourism stakeholders worldwide concerning e performance of their destination/business in the last four months and their expectations for the next four months. Figure 2 shows the expectations of future recovery and how expectations have changed over time, and the difference between regions. It is evident from the graph that the achievement of the level of values in 2019 should occur in 2023 - 2024. The most skeptical scenarios are characteristic of developments in Asia-Pacific and America.

Figure 2

Expected rate of recovery of international tourism according to UNWTO

\section{When do you expect international tourism to return to pre-pandemic 2019 levels in your country?}
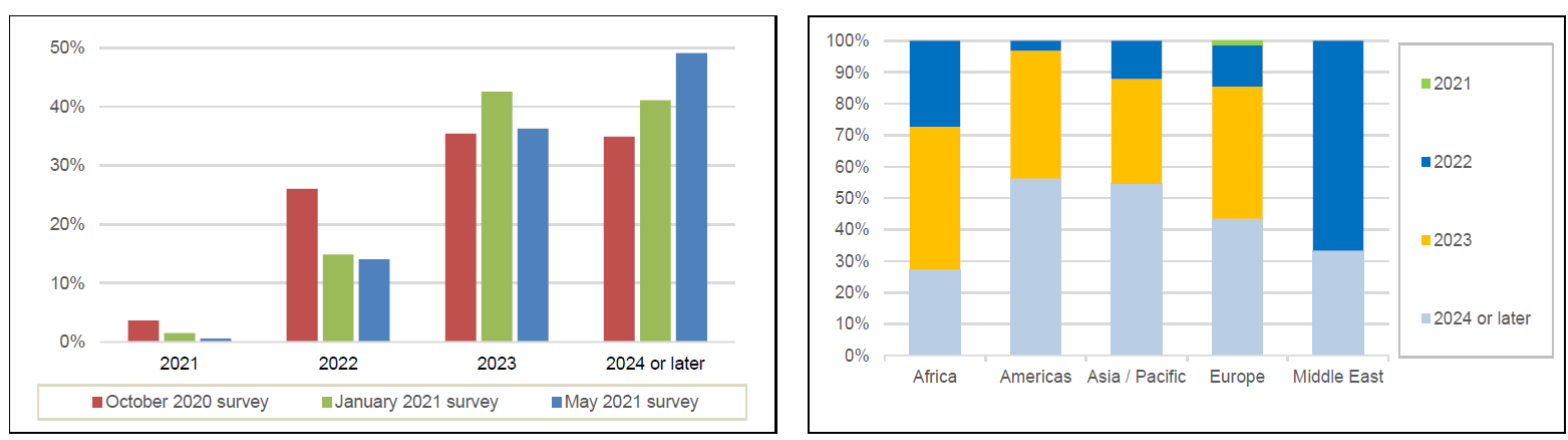

Source: UNWTO, 2021

Experts across the regions consider the easing of restrictions, slow virus containment, lack of coordinated response among countries, or low consumer confidence to be the main factors weighing on the recovery of international tourism. 
Very similarly, these factors are reflected in the potential pace of recovery in international air traffic.

\section{The actual situation in air transport after mid-2020}

The increasing volume of air transport before 2020 required that the demands on air transport were formulated in a timely and precise manner to ensure the efficiency of its operation, reliability, comfort, speed of transport, and, in particular, safety. For example, according to the International Air Transport Association (IATA), a total of 7.8 billion air passengers were expected to reach 2036, roughly double the registered 4 billion passengers in 2017 . The pandemic will significantly reduce these positive expectations.

In contrast to the risk situations of the previous growth of the volume of air traffic in the relatively short term, the events of the beginning of 2020 have a significantly more severe impact. The declared covid-19 pandemic has significantly dampened air traffic around the world. An example is the year-on-year percentage comparison of weekly scheduled flights worldwide and in three selected countries from January to June 2019 and 2020 indicated in table 1. A significant drop in air traffic volume is marked in red here.

Table 1

Year-on-year percentage difference of weekly scheduled flights (annual change 2020/2021)

\begin{tabular}{lcccccccccc}
\hline $\begin{array}{l}\text { Area of the } \\
\text { world }\end{array}$ & Jan. & Febr. & Mar. & April & May & $\begin{array}{c}\text { June } \\
\text { 1th }\end{array}$ & $\begin{array}{c}\text { June } \\
\text { 8th }\end{array}$ & $\begin{array}{c}\text { June } \\
15 \text { th }\end{array}$ & $\begin{array}{c}\text { June } \\
\text { 22th }\end{array}$ & $\begin{array}{c}\text { June } \\
\text { 29th }\end{array}$ \\
\hline World & $0,8 \%$ & $-8,6 \%$ & $-14,8 \%$ & $-64,5 \%$ & $-68,6 \%$ & $-65,1 \%$ & $-64,8 \%$ & $-62,6 \%$ & $-62,9 \%$ & $-56,0 \%$ \\
Germany & $-8,5 \%$ & $-6,9 \%$ & $-30,7 \%$ & $-92,9 \%$ & $-91,3 \%$ & $-91,4 \%$ & $-88,8 \%$ & $-84,9 \%$ & $-83,8 \%$ & $-76,2 \%$ \\
USA & $1,7 \%$ & $1,2 \%$ & $-2,2 \%$ & $-56,9 \%$ & $-74,2 \%$ & $-71,8 \%$ & $-67,9 \%$ & $-66,6 \%$ & $-65,1 \%$ & $-57,4 \%$ \\
\hline China & $4,3 \%$ & $-55,1 \%$ & $-40,2 \%$ & $-42,6 \%$ & $-28,8 \%$ & $-19,8 \%$ & $-21,2 \%$ & $-17,9 \%$ & $-23,9 \%$ & $-21,2 \%$ \\
\hline
\end{tabular}

Source: Outlook for Air Travel in Next 5 Years IATA (Pearce, 2020)

According to IATA, which brings together 220 airlines, the indicated drop in air traffic volume was a drop in the revenue to $\$ 419$ billion, $50 \%$ less than in 2019 . In 2020, IATA member airlines lost an average of $\$ 230$ million every day as passengers dropped to 2.25 billion. According to the head of the IATA financial group, this decrease in the volume of air traffic meant a loss, which corresponds to one decade of the previous increase in the volume of air traffic. Although passenger interest in air transport is gradually returning, the IATA financial group expects AT to continue to make losses in 2021, but airline damage could fall to $\$ 15.8$ billion (Eurocotrol, 2013). 
Figure 3

The scenario of Post Covid Growth Global RPK)

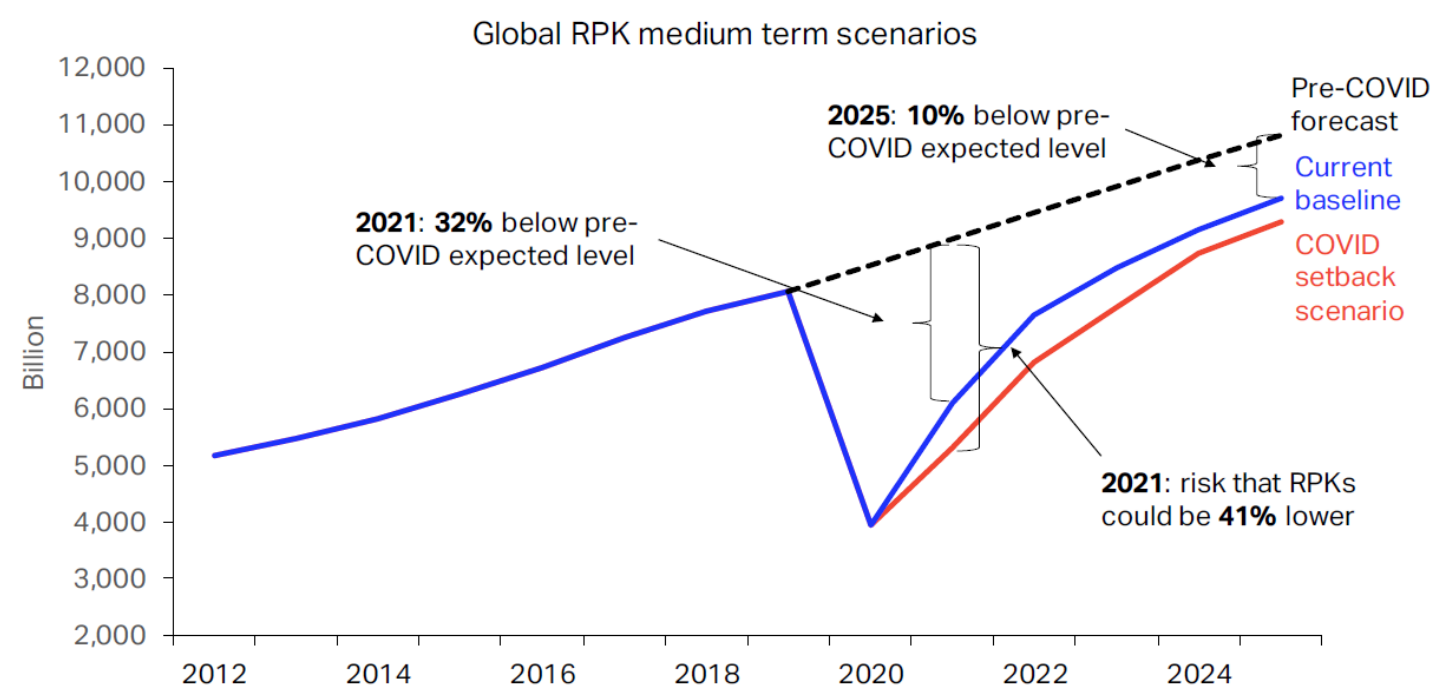

Source: Outlook for Air Travel in Next 5 Years IATA (Pearce, 2020)

The scenario of a recovery in air transport in the upcoming years is shown in Figure 3. According to Pearce (2020), air transport is likely to recover more slowly than in other sectors of the economy. For example, the level of the Global RPK (revenue passenger kilometers) from 2019 may be restored in 2023 - 2024, 3-4 years after the GDP recovery. Thus, with a lower forecast of the Global RPK level, it can be expected that the return to growth after covid-19 in 2021 will be about $32 \%-41 \%$ below the expected level (Figure 3).

The tourism and air transportation market crisis can be described based on general definitions of the crisis as a severe disruption of the tourism and aviation market with potentially adverse effects on the real economy. This is a situation of significant deterioration of critical indicators of the tourism market, which is reflected in insufficient liquidity, extensive insolvency, a significant decline in the value of financial and non-financial assets, and a significant reduction in the allocation of savings in the tourism sector.

Crisis management implemented by companies or industries focuses on addressing the effects of the crisis in financial losses, loss of reputation, and threats to public health and safety. The role of the public sector in crisis management and reviving the sector lies primarily in the responsible setting of the framework of tourism policy and transport policy.

In the literature, the concept of crisis management can take various forms, from crisis management as an administrative approach to deal with crisis conditions and to prepare a plan of confrontation to a more complex approach covering economy, sociology, psychology, and other sciences (Al-Helou, 2011). Quarantelli (1988), Voogd (2004), and other deal with the concept of decision-makers, control, coordination as relevant procedures for anticipating and preparing for the unknown. The way to overcome a crisis using the behavioral approach, reducing chaos by collecting information about threats without being subject to excessive and false optimism, is analyzed by Mirvis (1996) or Muffet-Willett et al. (2009). Landau et al. (1995) recommend institutions to establish and promote disappointment based on 
strategic approach and reality evaluation rather than biased self-deception and vigilance when confronting crises.

Theoretical approaches agree on the need for prepared and professional information-based crisis management, clearly defined procedures and strategies, including sectoral policies (transport policy, tourism policy, and related) typical of the public sector.

The primary content of transport policy (in civil aviation) is, in addition to the growth of air traffic, its support by promoting the process of liberalization in the field of air transport and the growing economic power of the population in many parts of the world.

Tourism policy sets the direction for destination tourism and creates a framework for destination management. Tourism policy in the international environment is a set of rules, documents, legislative and other instruments that serve to achieve goals set at the national and international level. Mundt (2004, p.12) defines tourism policy as "... a set of measures of public institutions at all levels of political action, which directly or indirectly, consciously or unconsciously, determine the formation and form of tourism."

Tourism destination management in the sense of destination governance means a complete set of internal and external mechanisms of power, rules, processes, and control to develop public sector policies and private sector business strategies leading to the achievement of set goals (Beritelli et al., 2007). The concept of destination governance is characterized by complexity, interconnection of the private and public sectors, and interdependence on resources (Zhang et al., 2014).

Strategic management of tourism and air transport companies or public sector entities means implementing strategic and tactical steps. Strategic management refers to setting objectives, researching, analyzing the internal organization and external environment, evaluating strategies concerning resources available to the company to set long-term goals and objectives.

\section{Analysis of primary statistical data}

A closer look at the demand in international tourism and air transport shows a quantitative market collapse. It indicates the trends and challenges that are most likely to accompany the further development of the sector. When monitoring the dynamic of international arrivals and the international receipts in the last five-year period, the following conclusions can be drawn (Table 2):

- Compared to the previous continuous growth of international arrivals, international tourism recorded a dramatic annual decline of almost $73 \%$ in 2020. Estimates of the decline in the first five months of $2021 / 2020$ are close to $65 \%$ and estimate January - May $2021 / 2019$ to $85 \%$.

- A similar trend is followed by revenues from international tourism when their year-on-year decline in 2020 reached $64 \%$ worldwide.

- A more detailed view of the individual regions (Europe, Americas, Asia-Pacific, Middle East, and Africa) shows the different dynamics of the decline and recovery depending on the measures and restrictions introduced in the tourism sectors and the international air transport sector in the countries concerned.

- The decline in international (and domestic) demand was logically reflected in decline in tourism's economic impact on the world economy. According to recent estimates, world GDP in tourism decreased by $3,7 \%$ in 2020 , suffering a loss of almost 4,5 trillion USD to reach 4,7 trillion USD (WTTC, 2020c). The total impact of tourism on global GDP has decreased from 10,4 \% in 2019 to $5,5 \%$ in 
2020 due to strict rules for access to destinations, international air transport, and ground-handling services provided at the destination.

- Demand in international tourism has partially shifted to domestic tourism, although domestic tourism is also negatively affected by the pandemic. Spending of domestic visitors declined by $45 \%$ globally, compared to an almost $70 \%$ drop in international visitor spending.

Table 2

International arrivals and tourism receipts 2018 - 2020

\begin{tabular}{|c|c|c|c|c|c|c|c|c|c|c|}
\hline \multirow[t]{2}{*}{ Territory } & \multicolumn{5}{|c|}{ International arrivals (million) } & \multicolumn{5}{|c|}{$\begin{array}{l}\text { International tourism receipts (billion USD, } \\
\text { local currencies, constant prices) }\end{array}$} \\
\hline & 2018 & 2019 & $19 / 18$ & 2020 & $20 / 19$ & 2018 & 2019 & $19 / 18$ & 2020 & $20 / 19$ \\
\hline World & 1413 & 1466 & $3,8 \%$ & 398 & $-73 \%$ & 1460 & 1446 & $2,9 \%$ & 536 & $-64 \%$ \\
\hline $\begin{array}{l}\text { Advanced } \\
\text { economies }\end{array}$ & 761 & 777 & $2,1 \%$ & 212 & $-73 \%$ & 948 & 922 & $1,3 \%$ & 357 & $-62 \%$ \\
\hline $\begin{array}{l}\text { Emerging } \\
\text { economies }\end{array}$ & 651 & 689 & $5,7 \%$ & 186 & $-73 \%$ & 512 & 544 & $6,0 \%$ & 179 & $-67 \%$ \\
\hline Europe & 716 & 743 & $4,2 \%$ & 235 & $-63 \%$ & 485 & 572 & $4,3 \%$ & 234 & $-60 \%$ \\
\hline Americas & 216 & 218 & $1,5 \%$ & 70 & $-68 \%$ & 370 & 323 & $-0,6 \%$ & 127 & $-60 \%$ \\
\hline Asia-Pacific & 346 & 360 & $4,0 \%$ & 57 & $-84 \%$ & 286 & 441 & $1,0 \%$ & 133 & $-70 \%$ \\
\hline Africa & 69 & 70 & $4,6 \%$ & 18 & $-74 \%$ & 33 & 39 & $2,1 \%$ & 14 & $-64 \%$ \\
\hline Middle East & 66 & 70 & $4,6 \%$ & 18 & $-74 \%$ & 63 & 91 & $20 \%$ & 29 & $-69 \%$ \\
\hline
\end{tabular}

Source: UNWTO (2021)

Research into the effects of the pandemic on global tourism employment shows that the number of jobs has decreased annually by 62 million in 2020 (-18,5\%), leaving 272 million jobs worldwide. Nevertheless, a further decline in jobs in tourism can be expected, given the supportive measures and retention schemes applied by national governments in 2020 and at the beginning of 2021. The decline in spending on business tourism (2020) outpaced the decline in spending on leisure tourism, falling by $61 \%$ compared to a $49 \%$ drop in the leisure tourism segment. Regarding the tourism development in the Czech Republic, the depth of the drop of the leading indicators is similar to that in the world economy (Table 3).

Table 3

Incoming and domestic tourism in the Czech Republic 2017 - 2021 (mil. arrivals/overnights, \% annual change)

\begin{tabular}{|c|c|c|c|c|c|c|c|c|c|c|}
\hline $\begin{array}{l}\text { Arrivals and } \\
\text { overnights in the } \\
\text { collective } \\
\text { accommodation } \\
\text { establishments }\end{array}$ & 2017 & $17 / 16$ & 2018 & $18 / 17$ & 2019 & $19 / 18$ & 2020 & $20 / 19$ & $\begin{array}{l}2021 \\
(1 . \mathrm{H})\end{array}$ & $\begin{array}{c}21 / 20 \\
(1 . H)\end{array}$ \\
\hline Intnl* arrivals (CEE) & 10,2 & $9,0 \%$ & 10,6 & $4,4 \%$ & 10,9 & $2,6 \%$ & 2,8 & $-74,4 \%$ & 0,286 & $-82,5 \%$ \\
\hline $\begin{array}{l}\text { Intnl* overnights } \\
\text { (CEE) }\end{array}$ & 26,3 & $8,2 \%$ & 26,8 & $1,9 \%$ & 27,2 & $1,6 \%$ & 7,4 & $-72,8 \%$ & 0,731 & $-83,8 \%$ \\
\hline $\begin{array}{l}\text { Domestic arrivals } \\
\text { (CEE) }\end{array}$ & 9,8 & $8,5 \%$ & 10,6 & $8,1 \%$ & 11,1 & $4,4 \%$ & 8,1 & $-27,5 \%$ & 1,6 & $-39,2 \%$ \\
\hline $\begin{array}{l}\text { Domestic } \\
\text { overnights (CEE) }\end{array}$ & 27,0 & $6,0 \%$ & 28,8 & $6.6 \%$ & 29,8 & $3,8 \%$ & 24,0 & $-19,6 \%$ & 4,6 & $-37,2 \%$ \\
\hline
\end{tabular}

Source: Czech Statistical Office Czech Statistical Office (2021)

Note: *International

According to data on the number of persons accommodated in collective accommodation establishments (Czech Statistical Office, 2021), international arrivals 
and overnights annually decreased by $74,4 \%$ and $72,8 \%$ in 2020 . Domestic arrivals and overnight stays dropped slightly lower and reached $28 \%$ and $20 \%$, respectively.

\section{Analysis of strategic documents}

Strategic documents' content analysis and comparison aim to answer the crisis management methods and what recommendations are proposed by international organizations for the revitalization of both international and air transportation sectors.

In May 2020, the UNWTO identified five priorities for revitalizing the tourism market: (UNWTO, 2020b-f, h):

1. Ensuring liquidity for companies and protection of jobs.

2. Restoring demand confidence through safety and hygiene measures.

3. Public-private cooperation to support tourism renewal.

4. Border opening based on due diligence and responsibility.

5. Harmonization and coordination of protocols and procedures.

6. Use of new technologies for maintaining and creating qualitatively new jobs.

7. Innovation and sustainability as a new normal state.

These priorities have been developed into themes, draft measures, and solutions, including safe traffic management and border crossings (airports, sea, land borders), setting rules and measures (protocols) across sectors, safe air transport, and other tourism sectors, including destination management.

In its recommendations, the WTTC emphasizes four main methods and tools, which provide guidance not only for the current solution of the situation but especially for the reconfiguration of tourism and related policies in the long term (WTTC, 2020a, b, d). Quantitative and qualitative development of demand, measures related to health and hygiene, innovation and digitization, and sustainability.

Like the UNWTO, WTTC emphasizes promoting changes brought about or strengthened by pandemics in national tourism policies and international coordination to ensure the resilience of tourism and related industries.

A comparison of the international organizations' methods, approaches, and measures (esp. UNWTO and WTTC), including expert recommendations, can be summarized. The recommended solutions proposed by individual organizations, despite their different scope and purpose, clearly agree in the emphasis on the following areas:

- Employment in tourism and rescue of more than 100 million vulnerable jobs worldwide.

- Support for entrepreneurship (small, medium-sized enterprises and large multinational companies) in direct and indirect sectors related to tourism, especially in the form of immediate fiscal measures, ensuring liquidity and protection of existing jobs (reduction of working hours, tax deferral, social security, and more) ).

- Restoration of consumer confidence and positive expectations thanks to the measures taken in individual countries, at the level of individual sectors and tourism facilities.

- Emphasis on innovation and digitization of the tourism sector to increase the resilience of tourism to crisis phenomena.

- Sustainability as a framework for restructuring the entire tourism industry and individual sectors (accommodation, transport, travel agencies, and others).

The strategic crisis-solving tools focus comprehensively on governments, destinations, the private sector, visitors, residents, and other interest groups. They recommend implementing the proposed procedures in the implemented national tourism and air transport policies. Both organizations consider a strategic and 
coordinated approach within individual countries, based on cooperation between the private and public sectors, and international coordination to be critical.

Although the Czech public sector has prepared and applied standard tools for short-term support to the tourism and air transport sectors in 2020/2021 (e.g., tax deferrals, wage subsidies, employment of financial instruments), there are significant gaps in long-term strategic management and a lack of the implementation of crisis management methods towards structural changes. The public sector has not yet captured the qualitative challenges and the overall change in the sector.

\section{Discussion}

Previous analysis of fundamental quantitative indicators and strategic documents published by leading international organizations in tourism and air transport clearly shows that managing the crisis in (international) tourism and (international) air transport means accepting the principles and methods of crisis management not only in the private sector but especially in the public sector.

All of the mentioned crisis methods, recommendations, and measures follow sustainability principles in the long term. The gradual quantitative increase of indicators to the level of 2019 will be accompanied by the reconstruction of the sector and by fundamental qualitative changes in both sectors towards sustainability as a new normal (UNWTO, 2020a, $\mathrm{f}, \mathrm{g}$ ).

Crisis and strategic recovery management are based on the following methods and principles in connection with already visible market trends.

Strategic approach by the public and private sector - creating practical tourism and transport policies driven by rational decisions, not political motives. There are two scenarios available to public institutions. First, they will address the situation by "simply" using public resources so that the ruling political party does not lose political points but cannot determine the strategic direction in the long run. Second, they will help overcome the crisis by mobilizing public resources and setting a strategic outlook for the sector's development based on the creation of conditions and financial resources, both indirect and non-financial, for the private sector. The role of the public sector in bridging the crisis and the role of a strategic leader for the new formation of the sector is irreplaceable.

Private sector - new business models - In setting up innovative business models associated with product development and distribution chain creation (entrances to international markets), we can expect changes towards reducing the cost of trade and marketing activities, their more significant focus, a shift to share specific links in the distribution chain and shifts to the so-called platform economy (platform economy). The development of e-commerce and online shopping is a noticeable trend in international tourism and air transport. The transition to digital platforms and the public sector's development of a business environment (setting sectoral policies) represent prerequisites for developing sustainable products, partnerships, etc.

Changes in the marketing mix and product development - In times of crisis, the public sector reviews tourism policy and related strategies and policies. It is essential to measure the impact of the pandemic on-demand and qualitative changes in demand in international tourism and air transport. Strategic management and marketing mix can be implemented only under the conditions of sufficient quality information about markets, competition, consumers, etc., in the public and private sector (market intelligence). Product development is adapted to the new requirements of source markets and segments, focusing on sustainability, quality, authenticity, and building a strong product brand. 
Digitization in the public and private sector - The success of strategic and crisis management of international tourism and international air transport depends on the degree of digitization and the progress made in digitizing the public sector agenda. Differences in the level of digitization in European destinations were already apparent before the crisis broke out, which has deepened them dramatically in the last year. Within the set tourism policy, it would be desirable to expect from the public sector (educational) programs associated with digitizing the private sector supported by financial and non-financial instruments.

Innovation and education - Tourism can exist only under conditions of mobility given by technical and technological progress. The challenges in this area lie in the further development of non-contact technologies (airports, airlines, hotels, and others) associated with the further development of biometrics, automatic identification, and self-service services.

Demands for hygienic measures are reflected in the use of robotics and automation in disinfection, cleaning, measuring clients' temperature, and cleaning with ultraviolet radiation. Tools for monitoring and video analysis of traffic streams are beginning to be implemented to maintain spacing and manage traffic (so far, especially at airports). A separate area is the provision of internationally usable digital health (vaccination) passports (CommonPass, Travel Pass).

The preparation and implementation of a strategy based on digitization focused on domestic and foreign markets and based on severe and continuous analysis means a shift in demands for education and training of new jobs and professionals. The training of professionals' is relevant both the public and private sectors, whose interdependence will strengthen much more than before the pandemic. A specific group for education is young people and women, who make up the majority of lower and middle positions in tourism and air transport.

A new aspect of personal communication between the customer and the employee is the increased sensitivity of customers and employees due to difficult conditions (e.g., fears of infection, use of safety equipment). Platforms for sharing information, experiences, workshops, implementation of artificial intelligence, the Internet of Things, big data and expert analytical work with data (market intelligence), and other forms of education are essential for the strategic and longterm recovery of the sectors concerned.

\section{Conclusion}

The public sector (public finances) will play a vital role in overcoming the crisis (application of support instruments for the survival of the sector). However, the role of the public sector is even more important in the phase of responsible strategic planning of sustainable supply and consumption. To adapt to new market conditions, market operators (destinations, private entities, airlines, and others) will strengthen the strategic approach, including strategic management (UNWTO, 2020h).

Strategic approaches in crises are essential not only in the private but primarily in the public sector. The public sector sets the general framework for tourism and air transportation policy.

Strengthening the institutional framework and setting relevant tourism policies and transport policies become the basic preconditions for the renewal of tourism at the level of national destinations in particular. Growth scenarios and sectoral development priorities are no less important, such as involving sustainability principles, changing marketing mix, involving local communities, promoting local 
products, and, on the other hand, creating global digital platforms through investment in digital systems and education (UNWTO, 2020b, h, WTTC, 2020d).

Crisis and strategic recovery management are based on the following methods and principles in connection with already visible market trends.

Methods, tools, and recommendations for temporary crisis and long-term strategic management consist of following: (i) A strategic outlook for the development of the sector based on the creation of conditions and financial resources; (ii) Private sector - new business models; (iii) Changes in the marketing mix and product development, (iv) Digitization in the public and private sector; and (v) Innovation and education.

The crises and recovery schemes and frameworks recommended by the international organizations to governments and other entities incorporate sustainability principles. The inclusion of sustainable tourism in national, regional and international tourism renewal programs with links to relevant financial instruments, strengthening the tourism management system at all levels of support for the transformation to a circular economy, and the adoption of the 2030 Sustainable Development Goals are recommended to be implemented in both the public and private sector.

\section{References}

1. Al-Dabbagh, Z. S. (2020), "The Role of Decision-maker in Crisis Management: A qualitative Study Using Grounded Theory (COVID-19 Pandemic Crisis as A Model)", Journal of Contingencies and Crisis Management, Vol. 20 No. 4, pp. 1-11.

2. Al-Helou, G. (2011), "School crises in government secondary schools in the northern west bank directorates", An-Najah University Journal, Vol. 24 No. 1, pp. 223-262.

3. Beritelli, P., Bieger, T., Laesser, C. (2007), "Destination governance: Using corporate governance theories as a foundation for effective destination management", Journal of Travel Research", Vol. 46 No. 1, pp. 96-107.

4. Czech Statistical Office (2021), "Tourism Time Series", available at: https://vdb.czso.cz/vdbvo2/faces/cs/index.jsf?page=statistiky\&katalog=31742\#katalo $g=31743$ (30 July 2021)

5. Eurocotrol (2013), "Challenges of Growth 2013, Task 7: European Air Traffic in 2050", available

https://www.eurocontrol.int/sites/default/files/article/content/documents/officialdocuments/reports/201306-challenges-of-growth-2013-task-7.pdf (2 April 2021)

6. European Commission (2021), "Europe's Vision for Aviation Flightpath 2050", available at https://ec.europa.eu/transport/sites/default/files/modes/air/doc/flightpath2050.pdf (10 April 2021)

7. Landau, M., Chisholm, D. (1995), "The arrogance of optimism: Notes on failure avoidance management", Management Science, Vol. 3 No. 2, pp. 67-80.

8. Mirvis, P. (1996), "Historical foundations of organization leasing", Journal of Organizational Change Management, Vol. 9 No. 1, pp. 13-31.

9. Muffet-Willett, S., Kruse, S. D. (2009), "Crisis leadership: Past research and future directions", Journal of Business Continuity \& Emergency Planning, Vol. 3 No. 3, pp. 248258.

10. Mundt, J. W. (2004), Tourismuspolitik, Oldenbourg Wissenschaftsverlag, München.

11. Pearce, B. (2020), "COVID-19 Outlook for air travel in the next 5 years, IATA", available at: https://www.iata.org/en/iata-repository/publications/economic-reports/covid-19outlook-for-air-travel-in-the-next-5-years/ (2 May 2021)

12. Prevor, D. (2018), "Global Market Forecast, ICAO, Airbus GMF 2018", available at: https://www.airbus.com/content/dam/corporate-topics/financial-and-companyinformation/JP-Morgan-GMF.pdf (1 May 2021)

13. Quarantelli, E. (1988), "Disaster crisis management: A summary of research findings". Journal of Management Studies, Vol. 25 No. 4, pp. 373-385. 
14. UNWTO (2008), International Recommendations for Tourism Statistics (2008), Series M No. 83/Rev.1. 2010, New York.

15. UNWTO (2020a), "Sustainability as the new normal" A vision for the future of tourism", available at: https://www.unwto.org/covid-19-oneplanet-responsible-recovery (15 May 2021)

16. UNWTO (2020b), "Covid-19 Tourism Recovery Technical Assistance Package", available at: https://webunwto.s3.eu-west-1.amazonaws.com/s3fs-public/202005/COVID-19-Tourism-Recovery-TA-Package_8\%20May-2020.pdf (15 May 2021)

17. UNWTO (2020c), "Covid-19: Measures to Support Travel and Tourism", available at: https://www.unwto.org/covid-19-measures-to-support-travel-tourism (10 May 2021)

18. UNWTO (2020d), "Five Priorities For Tourism's Restart", available at: https://www.unwto.org/tourism-and-covid-19-unprecedented-economic-impacts (5 May 2021)

19. UNWTO (2020e), "Global Guidelines To Restart Tourism", available at: https://webunwto.s3.eu-west-1.amazonaws.com/s3fs-public/2020-05/UNWTO-GlobalGuidelines-to-Restart-Tourism.pdf (6 May 2021)

20. UNWTO (2020f), "Impact Assessment of The Covid-19 Outbreak on International Tourism", available at: https://www.unwto.org/impact-assessment-of-the-covid-19outbreak-on-international-tourism (17 May 2021)

21. UNWTO (2020g), "One Planet Vision for a Responsible Recovery of the Tourism Sector" available at: https://webunwto.s3.eu-west-1.amazonaws.com/s3fs-public/202006/one-planet-vision-responsible-recovery-of-the-tourism-sector.pdf ( 11 May 2021)

22. UNWTO (2020h), "Supporting Jobs and Economies Through Travel and Tourism", available at: http://webunwto.s3.eu-west-1.amazonaws.com/s3fs-public/202004/COVID19_Recommendations_English_1.pdf (17 April 2021)

23. UNWTO (2021), "World Tourism Barometer", available at: https://www.eunwto.org/doi/epdf/10.18111/wtobarometereng.2021.19.1.3 (3 June 2021)

24. Voogd, H. (2004), "Disaster prevention in Urban Environment", available at: https://citeseerx.ist.psu.edu/viewdoc/download?doi=10.1.1.365.6313\&rep=rep 1\&type= pdf (1 June 2021)

25. WTTC (2020a), "Recovery Scenarios 2020 \& Economic Impact from COVID-19", available at: https://wttc.org/Research/Economic-Impact/Recovery-Scenarios (1 June 2021)

26. WTTC (2020b), "To Recovery \& Beyond: The Future of Travel \& Tourism in the Wake of COVID-19", available at: https://wttc.org/Research/To-Recovery-Beyond (27 May 2021)

27. WTTC (2020c), "Travel Demand Recovery Dashboard", available at: https://wttc.org/Initiatives/Recovery-Dashboard (30 May 2021)

28. WTTC (2020d), "WTTC Government Covid-19 Strong Policies" available at: https://wttc.org/COVID-19/Government-Policies (15 June 2021)

29. Zhang, H., Zhu, M. (2014), "Tourism Destination Governance: A Review and Research Agenda", International Journal of e-Education, e-Business, e-Management and eLearning, Vol. 4 No. 2, pp. 125-128. 


\section{About the authors}

Mr. doc. Ing. Jindrich Ploch, CSc. is the Rector Emeritus of the College of International and Public Relations in Prague and the Rector Emeritus of the University of Business in Prague. He has been working in the academic sphere for more than two decades. He is an expert in the field of international air transport. He represented the Czech Republic as a member of the EASA Management Board of the European Aviation Safety Agency (EASA) when he was General Director of the Civil Aviation Authority. His professional contribution to the quality transformation of civil aviation in the Czech Republic after the Czech Republic's accession to the EU is essential. Mr. doc. Ploch is a member of the MRD Strategic Council, president of the Alliance of Unmanned Industry of the Czech Republic (2015-2017), Member of the Scientific Board of the Faculty of Aviation of the Technical University of Kosice, Member of the Academic Council of the University of Economics in Prague (2013 2018), Member of the JAA Committee 2007), Member of the EASA Management Board (EASA - European Aviation Safety Agency) for the Czech Republic (20032007). He is also the guarantor of the study program Air Traffic Operation. The author can be contacted at email ploch@vsmvv.cz

Monika Palatková was the Director of the Czech Tourism Center - CzechTourism, a contributory organization of the Ministry for Regional Development, from 2015 to 2019. She also worked at the University of Business in Prague. Until 2014, she was the head of the Department of Tourism Economics and guarantor of specialized subjects in the fields of "Tourism" and "Tourism Management." Since 1998 she has been a member of the prestigious International Organization of Experts on Tourism AIEST. She was also a member of the processing team of the medium-term marketing strategy of the Czech Republic: Rebranding and Marketing Support of Inbound Tourism. She is also the Director of the Institute of International Management and Marketing. She is the guarantor of the study program International Marketing and Management. The author can be contacted at email palatkova@vsmvv.cz 